\title{
MEMBACA IDEOVISUAL UNTUK SISWA TUNARUNGU
}

\author{
Murni Winarsih \\ e-mail: mwinarsih@unj.ac.id \\ Pendidikan Luar Biasa, Fakultas Ilmu Pendidikan \\ Universitas Negeri Jakarta
}

Jl. Rawamangun Muka, Jakarta 13220

\begin{abstract}
Abstrak: Hambatan pendengaran menjadi dampak dalam pemerolehan bahasa anak tunarungu yang menyebabkan minim kosakata. Minim kosakata berdampak bagi anak tunarungu saat belajar membaca. Membaca bagi siswa tunarungu diajarkan bersamaan dengan menulis dan mengucapkan kata yang disebut membaca ideovisual. Membaca ideovisual adalah membaca ide-ide anak saat melakukan percakapan yang dituangkan dalam bentuk visualisasi berupa tulisan, gambar dan peragaan (bermain peran) sesuai konteks ide yg diungkapkan. Tujuan artikel ini adalah untuk memberikan pengetahuan tentang membaca ideovisual bagi siswa tunarungu. Membaca ideovisual merupakan bagian dari tahapan dalam melaksanakan Metode Maternal Reflektif (MMR) yang harus dilakukan oleh guru di lembaga pendidikan tunarungu sehingga dapat membantu dalam pemerolehan bahasa yang optimal.
\end{abstract}

Kata-kata kunci: membaca ideovisual, tunarungu, pemerolehan bahasa

\section{IDEOVISUAL READING FOR HEARING IMPAIRMENT STUDENT}

\begin{abstract}
Hearing impairments have an impact on the process of language acquisition of a student with hearing impairment causing a lack of vocabulary. This condition affects a student with hearing impairment while learning to read. Reading for a student with hearing impairment are taught simultaneously with the writing $n$ saying a word called ideovisual reading. Ideovisual reading is reading children's ideas while having a conversation that is contained in the form of visualization of text, images, and demonstration (role playing) according to the idea expressed. The purpose of this article is to provide knowledge about ideovisual reading for students with hearing impairment. Ideovisual reading is part of the stages in implementing the Maternal Reflective Method (MMR) should be done by teachers in hearing impairment education institution so it can assist the optimal of language acquisition.
\end{abstract}

Keywords: ideovisual reading, hearing impairment, language acquisition

\section{PENDAHULUAN}

Membaca adalah jendela dunia, melalui membaca kita mengetahui berbagai informasi yang terbaru dan lampau. Bagi anak yang tidak mengalami hambatan pendengaran bukan hal sulit untuk belajar membaca tetapi bagi anak yang mengalami hambatan pendengaran (tunarungu) membaca sangat sulit untuk dilakukan. Anak tunarungu adalah anak yang mengalami kesulitan mendengar dari gradasi ringan sampai berat, digolongkan ke dalam tuli dan kurang dengar, sehingga berdampak dalam memproses informasi yang menggunakan bahasa sekalipun sudah memakai alat bantu dengar tetap memerlukan layanan pendidikan khusus (Winarsih, 2007:22).

Akibat ketunarunguan yang dialami berakibat anak tidak mengalami masa pemerolehan bahasa, yang menyebabkan anak tunarungu sangat minim kosakatanya bahkan tidak memiliki bahasa sama sekali seperti bayi yang belum dapat bicara. Anak tunarungu yang sejak dini dimasukkan ke Sekolah Luar Biasa khusus tunarungu (SLB-B), dapat diberikan pembelajaran bahasa untuk menggantikan masa pemerolehan bahasa yang tidak dialaminya. Pendidikan yang diberikan di SLB-B tentunya berbeda dengan pendidikan pada umumnya. Pendidikan bagi anak tunarungu dapat diberikan sejak anak berusia 2 tahun. Sedini mungkin anak tunarungu diberikan intervensi pendidikan khususnya dalam bahasa, semakin cepat anak dapat mengusai bahasa.

Pendidikan bagi anak tunarungu usia dini dalam proses pembelajaran diarahkan untuk mengembangkan kemampuan berbahasa, mulai dari belajar mengeluarkan suara hingga mengucapkan kata sampai anak memahami kata yang diucapkannya. Belajar berbahasa dilakukan dalam bentuk percakapan. Siswa dituntut untuk aktif berbicara sekalipun belum jelas apa yang dibicarakan. Guru harus membahasakan suara yang dikeluarkan oleh siswa dengan metode tangkap dan peran ganda. Dapat dibayangkan jika 
anak tunarungu terlambat diberikan pendidikan, semakin sulit dan tertinggal dalam kemampuan berbahasanya. Pembelajaran berbahasa bagi siswa tunarungu bersamaan dengan membaca, menulis dan mengucapkan/berbicara. Dalam artikel ini akan dibahas tentang membaca ideovisual yang merupakan kegiatan membaca bagi siswa tunarungu dalam proses pemerolehan bahasa.

\section{PEMBAHASAN}

Membaca adalah keterampilan melisankan dan mempersepsi bahasa tulis untuk memperoleh pesan yang disampaikan. Membaca ideovisual adalah membaca ide-ide anak yang diperoleh dari hasil percakapan kemudian divisualisasikan dalam bentuk gambar dan tulisan. Membaca ideovisual adalah membaca kalimat yang isinya telah diketahui dan dialami dalam kegiatan percakapan sebelumnya. Tujuan membaca ideovisual untuk memahami isi bacaan dan mengenal lambang grafis secara global intuitif (Tim guru PL, 2013:32).

Mengajarkan membaca kepada siswa tunarungu dapat diberikan sejak sedini mungkin, sejak anak dimasukkan dalam lembaga pendidikan, sejak itulah diberikan pembelajaran membaca. Jika anak tunarungu dimasukkan ke sekolah usia tiga tahun maka pada usia tersebut anak sudah dikenalkan dengan lambang bahasa tulis dan diajarkan membaca. Apakah menyalahi aturan dan mengganggu perkembangan psikologis anak? Jawabannya adalah benar bagi sebagian orang yang belum memahami siswa tuunarungu, hal ini menyalahi aturan pendidikan bagi anak usia dini yang belum diperbolehkan mengajarkan yang akademik terlebih membaca, namun bagi yang sudah memahami siswa tunarungu, membaca, menulis dan mengucapkan merupakan kegiatan yang wajib dilakukan dalam satu kesatuan proses pembelajaran.

Siswa tunarungu seperti telah dijelaskan sebelumnya, adalah siswa yang mengalami hambatan pendengaran yang berdampak tidak dialaminya masa pemerolehan bahasa. Masa pemerolehan bahasa yang seharusnya dialami saat masa perkembangan bahasa usia 0-2 tahun, namun tidak demikian bagi siswa tunarungu sehingga untuk mengatasi kehilangan masa pemerolehan bahasa tersebut diajarkanlah dalam proses pembelajaran bahasa di sekolah. Bagi lembaga pendidikan tunarungu yang menggunakan Metode Maternal Reflektif (MMR), pembelajaran bahasa dilakukan melalui percakapan. Percakapan yang dilakukan bersifat spontan dan wajar layaknya seorang ibu yang sedang bercakap dengan bayinya yang mendengar. Kegiatan percakapan dilakukan dimana saja, kapan saja dan tentang apa saja. Siswa tunarungu dibiasakan untuk mengungkapkan apa yang ada dalam pikirannya dalam wujud bahasa lisan/berbicara.

Hasil dari percakapan diolah dalam bentuk visualisasi dalam bentuk tulisan dan gambar (siapa? berkata apa?). Melalui proses ini guru berusaha menangkap apa yang diujarkan oleh siswa dan membahasakannya kembali dalam kalimat (metode tangkap dan peran ganda). Misalnya percakapan yang terjadi di kelas Persiapan-1 PAUD sebagai berikut.

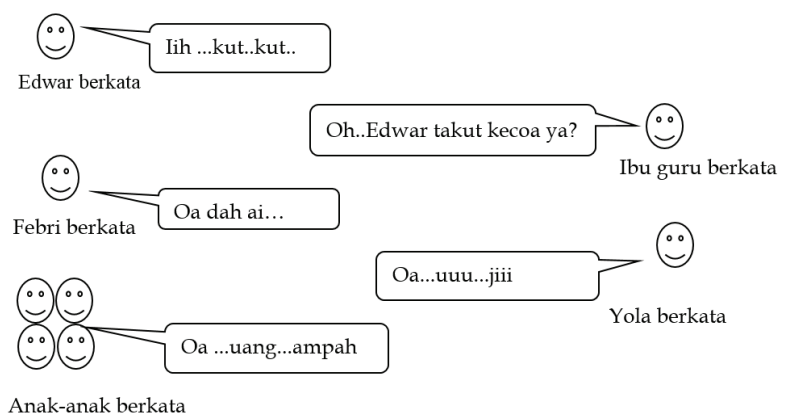

Gambar. Percakapan di kelas persiapan-1 PAUD

Penjelasan:

Percakapan di atas terjadi di kelas persiapan-1 pada jenjang PAUD usia 3-5 tahun, saat di kelas Edwar dengan ekspresi ketakutan melihat seekor kecoa di lantai dan ungkapan yang ingin disampaikan adalah "Saya takut ada kecoa" ungkapan ini ditangkap oleh ibu guru "Oh..Edwar takut kecoa ya?" kemudian Febri sambil menunjuk dan melihat kearah kecoa, ingin mengatakan bahwa "Kecoa sudah mati", sedangkan Yola dengan wajah jijik sambil menutup hidung dan menjauh ingin mengungkapkan bahwa kecoa bau dan saya jijik. Anak-anak lainnya sambil menunjuk ke tempat sampah ingin mengungkapkan agar kecoa segera dibuang ketempat sampah.

Demikian seandainya siswa tunarungu tersebut dapat bicara maka ungkapan-ungkapan seperti di atas kira-kira yang ingin disampaikan dan guru membahasakannya kembali agar ungkapan anak menjadi utuh.

Percakapan yang terjadi sebaiknya bersifat spontan, wajar dan sebisa mungkin siswa diminta berkata dengan segala kemampuan bahasa yang dimilikinya. Dari percakapan dilanjutkan dengan membahas satu persatu ungkapan siswa sampai menjadi bermakna dan siswa memahami kejadian/ peristiwa yang terjadi saat itu. Setelah percakapan sudah menjadi milik siswa (dipahami maknanya), 
maka dilanjutkan dengan menuliskan kembali dalam bentuk bacaan yang isinya menggambarkan peristiwa yang terjadi dalam percakapan tadi. Bacaan dibuat sederhana dengan kalimat yang berasal dari ungkapan-ungkapan siswa sehingga makna semakin dipahami. Setelah dibuat bacaan, dibuat pula gambar kecoa dan diberi tulisan "kecoa" di bawah gambarnya, gambar disajikan di samping bacaan dengan tujuan agar siswa tahu bacaan tersebut tentang kecoa. Setelah bacaan dibuat, guru meminta siswa membaca dalam hati, guru menunjukkan tulisan bacaan tadi. Selanjutnya guru membuat kelompok aksen yaitu memberi tanda aksen //............// atau tanda lengkung frase di bawah kalimat sesuai dengan cara pengucapannya, lalu siswa diminta membaca kalimat demi kalimat berdasarkan kelompok aksen tersebut.

Langkah-langkah dalam membaca ideovisual (Tim guru PL, 2013: 33) dapat dipersingkat sebagai berikut: (1) guru menyusun bacaan berdasarkan percakapan; (2) siswa membaca dalam hati; (3) siswa membuat kelompok aksen pada kalimat; (4) siswa diminta membaca kalimat demi kalimat sesuai kelompok aksen; dan (5) siswa mengartikan kalimat demi kalimat yang dibacanya, diperkuat dengan gambar, peragaan, dan dramatisasi.

Bacaan dari percakapan di atas dapat dibuat seperti berikut.

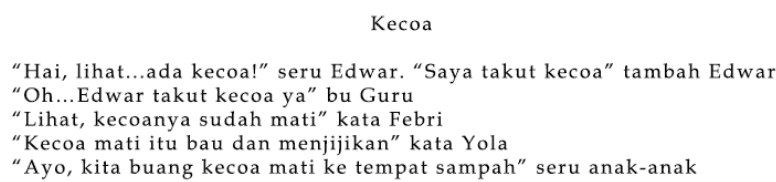

Bacaan di atas disusun berdasarkan percakapan, sehingga siswa tunarungu mudah memahami kalimat-kalimat yang ada dalam bacaan, karena sudah mengalami dan menghayati peristiwa tersebut sebelumnya. Jika ada anggapan bahwa membaca untuk anak usia dini melanggar dan mengganggu psikologis anak, maka bagi anak tunarungu sebaliknya membaca, menulis dan mengucapkan merupakan satu kesatuan yang tidak boleh ditinggalkan dalam proses pembelajaran. Pembelajaran membaca melalui membaca ideovisual berjalan dengan proses yang bertahap dan sangat sistematis sehingga tidak membuat siswa tunarungu terganggu psikologisnya. Materi membaca ideovisual dibuat dari hasil percakapan siswa yang dialami bersama sehingga masing-masing dapat lebih mudah memahami bacaan.

Ciri lain pembelajaran membaca ideovisual adalah ditulis dengan menggunakan huruf tegak bersambung. Hal ini dikarenakan huruf tegak bersambung saling mengait dan membuat kata demi kata tersusun dalam satu kesatuan yang utuh, berbeda jika menggunakan huruf cetak masing-masing huruf tersusun dan saling lepas. Siswa tunarungu lebih mudah memahami tulisan dengan penggunaan huruf tegak bersambung sesuai dengan pemahamannya yang bersifat global intuitif, hal ini diperkuat dengan teori belajar Gestalt yang menyatakan proses persepsi melalui pengoranisasian komponen-komponen sensasi yang memiliki hubungan, pola, ataupun kemiripan mejadi kesatuan (Hidayati, 2012:19). Membaca bagi siswa tunarungu usia dini dilakukan secara global intuitif sesuai dengan pemahaman siswa dan merupakan hasil percakapan yang diolah untuk memperdalam makna yang dikandung dari bacaan.

Membaca ideovisual sangat membantu siswa tunarungu untuk memahami kata dan pada akhirnya digunakan untuk memperoleh bahasa (bahasa menjadi milik anak). Setiap kalimat yang dibaca dibahas satu persatu maknanya, dan diulang-ulang terus sampai siswa memahami ungkapan yang disampaikan. Kegiatan membaca ideovisual ini tentunya tidak dalam satu pertemuan langsung dipahami, namun melalui proses yang panjang dan diawali dengan percakapan dari hati ke hati (Perdati) kemudian membaca ideovisual.

\section{PENUTUP}

\section{Kesimpulan}

Membaca merupakan keterampilan melisankan dan mempersepsi bahasa tulis untuk memperoleh pesan yang disampaikan. Membaca ideovisual adalah membaca ide-ide anak yang diperoleh dari hasil percakapan kemudian divisualisasikan dalam bentuk gambar dan tulisan. Membaca ideovisual adalah membaca kalimat yang isinya telah diketahui dan dialami dalam kegiatan percakapan sebelumnya. Membaca bagi siswa tunarungu dalam proses pembelajarannya tidak sama seperti belajar membaca umumnya, namun diajarkan melalui proses percakapan yang dilanjutkan dengan menyusun bacaan berdasarkan percakapan, membaca dalam hati, membuat kelompok aksen pada kalimat, membaca kalimat demi kalimat sesuai kelompok aksen, mengartikan kalimat demi kalimat yang dibacanya, diperkuat dengan gambar, peragaan, dan dramatisasi. Diharapkan melalui membaca ideovisual, siswa tunarungu dapat memahami isi bacaan dan mengenal lambang grafis secara global intuitif sehingga dapat menambah penguasaan kosakata serta meningkatkan 
kemampuan berbahasa lisan.

\section{DAFTAR PUSTAKA}

Winarsih, M. (2007). Intervensi dini tunarungu dalam pemerolehan bahasa. Jakarta: Direktorat Dikti.

Tim Guru Pangudi Luhur. (2013). Didaktik metodik pemerolehan kemampuan berbahasa anak tunarungu taman latihan dan observasi. Bantul, Yogyakarta: Percetakan Pohon Cahaya.

Hidayati, T. (2012). Implementasi teori belajar pada proses pembelajaran. Diakses dari http://jurnalfalasifa. files.wordpress.com/2012/11/1-titin-nur-hidayati-implementasi-teori-belajar-gestalt-pada-proses-pembelajaran-pdf. 